\title{
ADDING SHAREHOLDER VALUE THROUGH DIVIDEND POLICY: EVIDENCE FROM THE UNITED KINGDOM ON TAX-BASED SHAREHOLDER CLIENTELES
}

\author{
Sheila Killian \\ University of Limerick, Ireland \\ sheila.killian@ul.ie
}

December 2007

\begin{abstract}
This paper addresses the question of dividend clienteles based on shareholder-level taxation. In the United Kingdom in 1997, radical changes were made to the way in which the dominant shareholder clientele was taxed on dividend income. These changes provided a unique quasiexperimental opportunity for a direct test of dividend clienteles, and of tax theories. This issue is central to policy formation, and to predicting the likely impact on shareholder value of changes to the dividend policy pursued by firms.

Evidence is presented of two distinct tax-based clienteles in the United Kingdom, with contrasting preferences, one of which was strong enough to influence payout in the firms in which this clientele invested. The implication for South African firms is that, as the tax system changes, the payout preference of shareholders may also change. It is imperative that corporate financial managers react to these clienteles, and their requirements.
\end{abstract}

Keywords:

Taxation, dividends, clienteles, shareholder value, United Kingdom 


\section{INTRODUCTION}

Companies seek to add shareholder value, but often the impact of tax is inadequately considered. Practitioner journals advise on how to incorporate corporate-level taxes into decisions on investment, location, financing, etc. However, the taxes applied to shareholders on receipt of dividends do not receive the same attention. Theory suggests a clientele effect, and a firm which knows the dividend preferences of its shareholders will be at an advantage, by matching its payout policy to their needs. This paper raises and begins to address four questions:

- Do shareholder dividend clienteles exist?

- Are these clienteles based on tax or on other factors?

- Will investors compromise non-tax investment considerations to minimise taxation?

- Can firms add value by knowing their shareholder clientele?

These questions are examined in the context of tax changes that took place in the United Kingdom in 1997, which presented an opportunity to isolate the impact of shareholder level taxes. The tax position of shareholders is explicitly calculated rather than proxied, and a unique database incorporating ownership with company accounting data is used to test the hypotheses. The paper is organised as follows: Section 1 very briefly reviews the theory of tax-based dividend clienteles. Sections 2 and 3 outline the British system of dividend tax, explain the tax rules in force in the United Kingdom during the period studied, and the tax change, describe the clienteles in existence, and set out testable hypotheses on their dividend preferences in relation to the tax change. The research design and data used to test the hypotheses are described in section 4 . Empirical results are presented in section 5 . Section 6 discusses the robustness of the results and includes a summary and concluding remarks.

\section{TAX-BASED DIVIDEND CLIENTELE THEORY}

Most of our corporate finance theory has its origin in the United States of America. Historically, in the United States, there has been a significant tax-disadvantage to paying dividends, and so researchers have grappled with the question of why firms pay any dividends at all under these circumstances. It can be argued that this United States-based theory does not translate effectively to other jurisdictions, particularly across different taxation systems.

The tax system applying in the United States traditionally gave rise to an effective double tax on dividends. As described by Poterba and Summers (1985) and others, earnings were taxed in the hands of the firm, and when distributed, taxed in full again in the hands of the shareholder. Dividend payments do not reduce the corporation tax liability of the firm, in contrast with interest payments, which are in general fully deductible from taxable income. Dividends are therefore heavily taxed at the corporate level. At shareholder level, investors either pay income tax on dividends, or capital gains tax when they sell shares. Shackelford and Shevlin (2000) observe that since capital gains tax can be deferred or avoided by deferring sale, there is generally a tax advantage to the investor in holding growth shares, rather than those which pay out part of their value annually as dividends. Therefore dividends carry a tax penalty at both corporate and shareholder level. 
Despite the tax disadvantages, dividends continue to be paid. Researchers such as Gordon (1963) contend that dividends have inherent value, either as a signal of positive prospects for the firm, as mooted by Bhattacharya (1979), or as an attempt to overcome agency problems arising from the separation of ownership and control of the firm, as suggested by Easterbrook (1984). This would imply that high-payout firms trade consistently at a premium, which is patently not the case. Miller and Modigliani (1961) argue that dividend policy is irrelevant in the absence of taxation, and explain differences in payout between apparently similar firms as a response to the preferences of their shareholders. They argue that each firm attracts a "clientele" of like-minded investors, and in catering for that clientele, will maximise value.

The idea is that similarly taxed investors have similar payout preferences. Those with low income taxes prefer dividends, while those with higher income taxes, or capital losses to offset, prefer to take their return as a capital gain, and will favour low-payout firms. An efficient company attracts and attempts to cater for a particular clientele. This pairing of firms with investors leads to the absence of a direct relationship between returns and payout levels at aggregate level, but, insofar as the clientele-effect is the result of tax, an overall reduction in the tax cost of dividend payments.

\section{BRITISH TAX CLIENTELES IN RELATION TO THE 1997 TAX CHANGE}

Up to 1997, a partial imputation tax system was in place in the United Kingdom. Dividends paid to shareholders generated a tax credit based on the standard rate of corporation tax. As described by Poterba and Summers (1985), shareholders were taxed on the gross dividend (net cash received, plus tax credit), and their liability was discharged or reduced by the tax credit. Institutional shareholders, such as pension funds, were taxed at a rate of zero percent on dividends received. Since the tax credit could not reduce this nil liability further, these shareholders could reclaim it as an additional, tax-free cash dividend. This system of repayable tax credits created a marked tax preference for dividends among institutional investors.

To avoid gaming in the system, the amount of the tax credit was collected from the firms on payment of the dividend in the form of advance corporation $\operatorname{tax}$ (ACT). Payment of a dividend triggered an immediate company-level liability for ACT, which could eventually be set off against the firm's mainstream corporation tax (CT) on profits for the period. In general, provided that a firm had sufficient taxable income in the period to generate mainstream corporation tax, ACT did not represent an absolute cost. However, where a firm had losses, or used debt or other tax shields to reduce its overall liability to corporation tax, the ACT incurred by a dividend payment was surplus to immediate requirements. While such surplus ACT could be carried forward indefinitely, high levels of surplus ACT were a tax disincentive to paying dividends.

On 2 July, 1997, the first budget of an incoming Labour government abruptly abolished the repayable tax credits for institutional investors with immediate effect. The institutional context of this change is described in Robinson (2000). The abolition of ACT flowed inevitably from the removal of repayable tax credits, but was not announced until later in the year, and did not take effect until 1999. The abolition of the refundable tax credits increased the tax cost of paying dividends to pension funds, without changing their non-tax preferences. The tax position of individual shareholders was largely unaffected by the changes. The tax change thus provides a quasi-experimental opportunity to test directly for dividend clienteles based on shareholderlevel taxation. 
Arguably, individual shareholders are less informed than institutional investors, exacerbating agency issues for this clientele, and increasing the signalling value of dividends. Theory therefore suggests that individual investors have a non-tax preference for high payout. On the other hand, shareholder-level taxes should lead individual investors to favour low-payout firms. The payout pattern favoured by individual investors should therefore balance tax and non-tax factors. If a non-tax clientele exists, then the payout should be higher in firms with high individual ownership. If the clientele is based on tax, these firms should have lower payout.

Institutional shareholders also suffer from the separation of ownership and control, but agency costs are reduced by an improved flow of information. Firms have little need to use dividends as a signal to this group. Non-tax clientele theory suggests that these investors will favour a low payout, while tax rules indicate that prior to 1997 they would strongly favour a high payout. After the tax changes, non-tax incentives for a low payout continued, while shareholder-level tax considerations no longer demanded a high payout. This created a particularly interesting quasi-experimental setting in which to examine the trade-off of tax and non-tax factors within the clientele framework. If the strength of the relationship between payout levels and institutional ownership declines after 1997, it would appear that tax considerations outweigh non-tax factors. If the relationship remains strongly positive, non-tax considerations would appear to outweigh any tax-based clientele effect.

Prior to the tax changes, institutional investors had tax incentives to invest in high-payout firms. If tax factors can dominate traditional portfolio considerations for investors, their investment strategy would trade the benefits of the refundable tax credit off against the nontax benefits of portfolio diversification. Following 1997, investors following this strategy would need to diversify their portfolios, through a large-scale shift in investment from high-payout to low-payout firms, or change their policy for new investments, directing any new funds into lowpayout firms. The former course of action would involve placing large blocks of high-payout stocks on the market, which would adversely affect their market value. The latter policy would appear to be more plausible.

The hypotheses to be tested may be summarised as follows:

H(1): Firms with high individual ownership have a low dividend payout.

H (2): Firms with high institutional ownership have a high dividend payout

H(3): This relationship is less strongly positive after 1997

H (4): After 1997, institutional investors have altered their investment patterns

\section{RESEARCH DESIGN AND DATA ANALYSIS}

As can be seen from TABLE 1, the matching process involved merging data from the four different sources: accounting data from DataStream, firm age and technology markers from the London Stock Exchange website, membership of the FTSE 350 index from the Financial Times Stock Exchange, and ownership data from CityWatch. Since the period under study spans six years from 1995 to 2000, not all firms will have data for every year. The question arises: should firms with incomplete data be included in the dataset, or should the dataset be composed only of firms which have data in every year under study? 
TABLE 1: Construction of dataset

\begin{tabular}{|c|c|c|c|c|c|}
\hline Action & Source & Data & Criterion & $\begin{array}{c}\text { For } \\
\text { years }\end{array}$ & $\begin{array}{l}\text { Firm } \\
\text { Count }\end{array}$ \\
\hline Initial download & DataStream & Accounts data & & $\begin{array}{c}1990- \\
2000\end{array}$ & 1259 \\
\hline $\begin{array}{l}\text { Elimination of } \\
\text { differently-taxed } \\
\text { firms }\end{array}$ & DataStream & & $\begin{array}{l}\text { Financials, } \\
\text { exploration and } \\
\text { non-British firms }\end{array}$ & $\mathrm{n} / \mathrm{a}$ & 1020 \\
\hline Matching & LSE website & Age, TechMark & All firms & $\mathrm{n} / \mathrm{a}$ & 1020 \\
\hline Matching & FTSE & FTSE350 marker & All firms & $\begin{array}{c}1995- \\
2000\end{array}$ & 1007 \\
\hline Matching & CityWatch & $\begin{array}{l}\text { Shareholder } \\
\text { information }\end{array}$ & All firms & $\begin{array}{c}1995- \\
2000\end{array}$ & 1007 \\
\hline
\end{tabular}

Source: DataStream, LSE website, FTSE, CityWatch

DeAngelo, et al. (1992), following Miller and Modigliani (1961), argue for including only firms with established track records, on the basis that their dividend changes are more likely to be based on policy than smoothing requirements. By contrast, in a study based on capital structure, Miller, et al. (1994) follow Scholes and Wolfson (1992) in finding that capital structure is more likely to be based on tax requirements in newly public firms. On balance, since surviving firms are unlikely to be more representative of the United Kingdom market than others, firms with data only in some years are not eliminated. Tests on a balanced panel consisting only of firms with a full set of observations in each of the six years under study were also carried out, and those results were consistent with the larger sample.

\subsection{Research design}

The tests broadly fall into two groups: tests for the existence of a clientele examine relationships between ownership and levels of payout, while tests of influence relate ownership to changes in payout, or to decisions to increase or initiate the payment of dividends.

Initially, the sample is partitioned into quintiles based on the proportion of shares held by each clientele in each year. Payout levels in the top and bottom quintile are compared for each shareholder-type, and tested for significant difference. This provides a first test of hypotheses one and two: these tax-clientele hypotheses predict significantly lower payout in the top quintile of individual ownership, and significantly higher payout in the top quintile of institutional ownership in all years.

Secondly, regression analysis is used to isolate the impact of ownership on payout in each year. First dividend payout in each year is regressed on ownership and a series of control variables. This effectively isolates the explanatory effect of ownership, and constitutes a direct test for clienteles, testing directly hypotheses one to three.

The final hypothesis is tested in two strands. First the annual change in institutional investment in each firm is regressed on a series of explanatory and control variables in each year from 1996 to 2000 . A change in the sign or significance of key variables indicates a change in investment 
strategy.

Since institutional investors are the dominant clientele in the United Kingdom market, any change in their investment patterns should have a significant impact on the return on their target investments. As a second test for such rebalancing, the long-run return for high and low payout stocks is compared over the five years before and after the tax changes. If the dominant institutional clientele adjusted its investment strategy for new funds away from high-payout firms from 1997 onwards, high payout firms will out-perform low payout firms prior to the tax changes and the position will be reversed in the second period.

\subsection{Variable definition and descriptive statistics}

The principal variables used are payout, ownership, return, ACT and a series of control variables.

Fama and French (1998:822) criticise the use of dividend payout ratio, defined as current dividends to current earnings, explaining that is meaningless in the presence of losses, and "can explode when earnings are close to zero". They do not endorse the use of dividends scaled by price, on the basis that it can reflect non-dividend factors. To adjust for imputation and to remove tax effects from the variable, the net rather than gross dividend paid is used. To capture the discretionary element dividends paid on preference shares are excluded. The net dividend paid on ordinary shares is scaled by total assets rather than profits. While total assets can also be potentially unstable as a deflator, it is less so than any other profit measure, and avoids the problems associated with contemporaneous earnings management as a response to the $1997 \operatorname{tax}$ changes. Finally, it is winsorised, to reduce the effect of outliers on the regression analysis.

Individual ownership and institutional ownership are defined as the percentage of shares held by each category of shareholders, obtained from CityWatch. Data for individuals is available for the years 1997 to 2000 inclusive, while data on pension fund ownership is available from 1995 to 2000 , inclusive. As a simple measure of change in payout policy, the number of firms increasing payout in each year was determined. The change in institutional investment is used as a dependent variable in the regressions to test hypothesis four. Basic descriptive statistics for this variable in each year are given in TABLE 2.

TABLE 2: Descriptive statistics - change in institutional ownership

\begin{tabular}{lcccc}
\hline & $N$ & Minimum & Maximum & Mean \\
\hline$\Delta$ Ins, 1996 & 407 & 0,466 & 113,714 & 1,514 \\
$\Delta$ Ins, 1997 & 636 & 0,465 & 81,621 & 1,504 \\
$\Delta$ Ins, 1998 & 716 & 0,267 & 18,151 & 1,132 \\
$\Delta$ Ins, 1999 & 803 & 0,185 & 17,615 & 1,060 \\
$\Delta$ Ins, 2000 & 353 & 0,014 & 27,960 & 1,163 \\
\hline
\end{tabular}

Source: Tests by author on data, as described above

The variable is positive in all years, indicating that little or no disinvestment took place. This is consistent with the idea that institutional shareholders maintained their investments in high payout firms after the tax change. The average increase in investment decreases sharply from 1997 following the tax changes. This supports the idea that new funds are being spread more 
widely to achieve maximum portfolio diversification.

As a second test of the final hypothesis, the long-run returns on shares over the five years immediately preceding and following the tax changes are examined, to see how they relate to long-run payout levels. Two long-run return variables are defined. The pre-97 return is defined as the change in market capitalisation from 1991 to 1996, scaled by opening market capitalisation in 1991. The post-97 return is defined in a similar way, from 1996 to 2000. Longrun dividend payout is defined over a similarly long window on either side of the tax changes. The two variables are defined as the average of the ordinary dividends paid, scaled by total assets, from 1992 to 1996, and from 1997 to 2000, respectively.

As noted above, a firm with surplus ACT faced severe firm-level tax disincentives to paying dividends. Traditionally, surplus ACT has been detected using the reported figure of irrecoverable ACT, following Bond, et al., (1996). This is a conservative measure, due to the discretion allowed under SSAP 8, and the undesirable impact on profit of declaring ACT as irrecoverable. A four-point flag was designed based on actual payment patterns and tax rates from 1990 to 2000 to identify with more certainty firms with severe and moderate levels of surplus ACT, and those that fully or almost fully absorb their ACT in Mainstream Corporation Tax. Firms whose ACT status cannot be identified with reasonable certainty are separately labelled.

TABL $\boldsymbol{3}$ below summarises the variable.

TABLE 3: Summary of variable ACT flag

\begin{tabular}{ccc}
\hline Value of ACTflag & Identifies firms & Number \\
\hline 0 & ACT status uncertain & 469 \\
1 & Strong proxy for no surplus ACT & 142 \\
2 & Weak proxy for no surplus ACT & 228 \\
3 & Weak proxy for surplus ACT & 77 \\
4 & Strong proxy for surplus ACT & 91
\end{tabular}

Source: Tests by author on data, as described above

A number of other control variables are calculated. United States ownership is included as a control ownership variable. The United States clientele had weak and conflicting preferences for payout over the period of the tax changes, and theory would not predict a strong clientele effect associated with this group. The age of a firm is included on the basis that studies such as Fama and French (2000) find that younger firms pay lower dividends. Industry is defined as the threedigit industry code downloaded from DataStream. To control for low payout by technology firms, a dummy variable indicating whether or not the firm has the LSE designation TechMark is also included. Liquidity, which may be a constraint on the payment of dividends, is defined as cash flow from operations, scaled by total assets. Capital intensity, which makes borrowing easier, is defined as the proportion of fixed to total assets in the year.

Non-debt tax-shields reduce mainstream corporation tax, exacerbating the problem of absorbing the current ACT generated by dividend payments under imputation. To the extent that they impeded payout, they may be negatively related to payout until the abolition of ACT in 1999, and less significant thereafter. Following Bennett and Donnelly (1998) and Walsh and Ryan (1997), non-debt tax shields are proxied by deferred tax provided under SSAP 15. Gearing is 
included because debt and dividends may act as alternatives for the purposes of signalling or of reducing agency costs, because high interest payments will affect liquidity, reducing the levels of cash available to pay dividends, and because the tax shield afforded by debt could exacerbate a firm's surplus ACT position, thus inhibiting the ability to pay dividends. Following Wald (1999), long-term debt is used. Book values rather than market values are scaled by total assets, following Miller, et al., (1974) and Lasfer (1995).

Growth prospects, which should increase the need to signal, are proxied by a modified form of Tobin's $Q$, defined as market-to-book ratio. Size is included to deal with the possibility that institutional ownership may partially proxy for size, in which case its inclusion in the regressions would pick up only a size effect rather than the direct effect of ownership. Since many variables are scaled by total assets, size is proxied as the natural log of total assets to reduce potential multicollinearity problems.

\section{EMPIRICAL RESULTS}

Initially, payout levels in the top and bottom quintiles of individual and institutional ownership are compared. Hypotheses one and two would respectively predict lower payout with high individual ownership, and higher payout with high institutional ownership. TABLE 4 shows the aggregate payout, and results of t-tests comparing the top and bottom quintile in each ownership category.

TABLE 4: Dividend payout in top and bottom quintiles by ownership category

\begin{tabular}{|c|c|c|c|c|c|c|}
\hline Year & $\mathrm{N}$ & Mean & $\operatorname{lnd} \rho 1$ & IndQ5 & $\operatorname{lns} Q 1$ & $\operatorname{lns} 05$ \\
\hline 1995 & 701 & 0,0282 & - & - & $0,0229^{\star *}$ & 0,0318 \\
\hline 1996 & 785 & 0,0281 & - & - & $0,0217^{\star \star \star}$ & 0,0384 \\
\hline 1997 & 872 & 0,0287 & 0,0326 & 0,0261 & $0,0241^{\star \star}$ & 0,0337 \\
\hline 1998 & 942 & 0,0331 & $0,0416^{\star \star \star}$ & 0,0270 & 0,0292 & 0,0339 \\
\hline 1999 & 968 & 0,0276 & $0,0356^{\star \star \star}$ & 0,0236 & $0,0197^{\star \star \star}$ & 0,0325 \\
\hline 2000 & 967 & 0,0252 & $0,0329^{\star \star \star}$ & 0,0199 & $0,0179^{\star \star \star}$ & 0,0307 \\
\hline $\begin{array}{l}\star \star \star \\
\star \star \\
\star\end{array}$ & $\begin{array}{l}\text { Significar } \\
\text { Significar } \\
\text { Significar }\end{array}$ & $\begin{array}{l}\text { rent from } \\
\text { rent from } \\
\text { rent from }\end{array}$ & $\begin{array}{l}1 \% \text { level } \\
5 \% \text { level } \\
10 \% \text { level }\end{array}$ & & & \\
\hline Source: & \multicolumn{6}{|c|}{ Tests by author on data, as described above } \\
\hline \multicolumn{7}{|c|}{$\begin{array}{l}\text { Payout levels for firms with the low individual ownership is, as predicted, significantly lower than } \\
\text { in those firms with high individual ownership. Payout in the bottom quintile of institutional } \\
\text { ownership is in all cases significantly lower than payout in the top quintile, consistent with the } \\
\text { existence of an institutional tax clientele. The difference between the top and bottom quintiles } \\
\text { of institutional ownership is not significant in 1998, following the tax change, suggesting that } \\
\text { some adjustments were made in that year. Notably, from } 1998 \text { firms dominated by institutional } \\
\text { investors continue to have a significantly higher payout, in the absence of a tax incentive. This } \\
\text { suggests that the institutional clientele is also based on non-tax motivations. }\end{array}$} \\
\hline
\end{tabular}




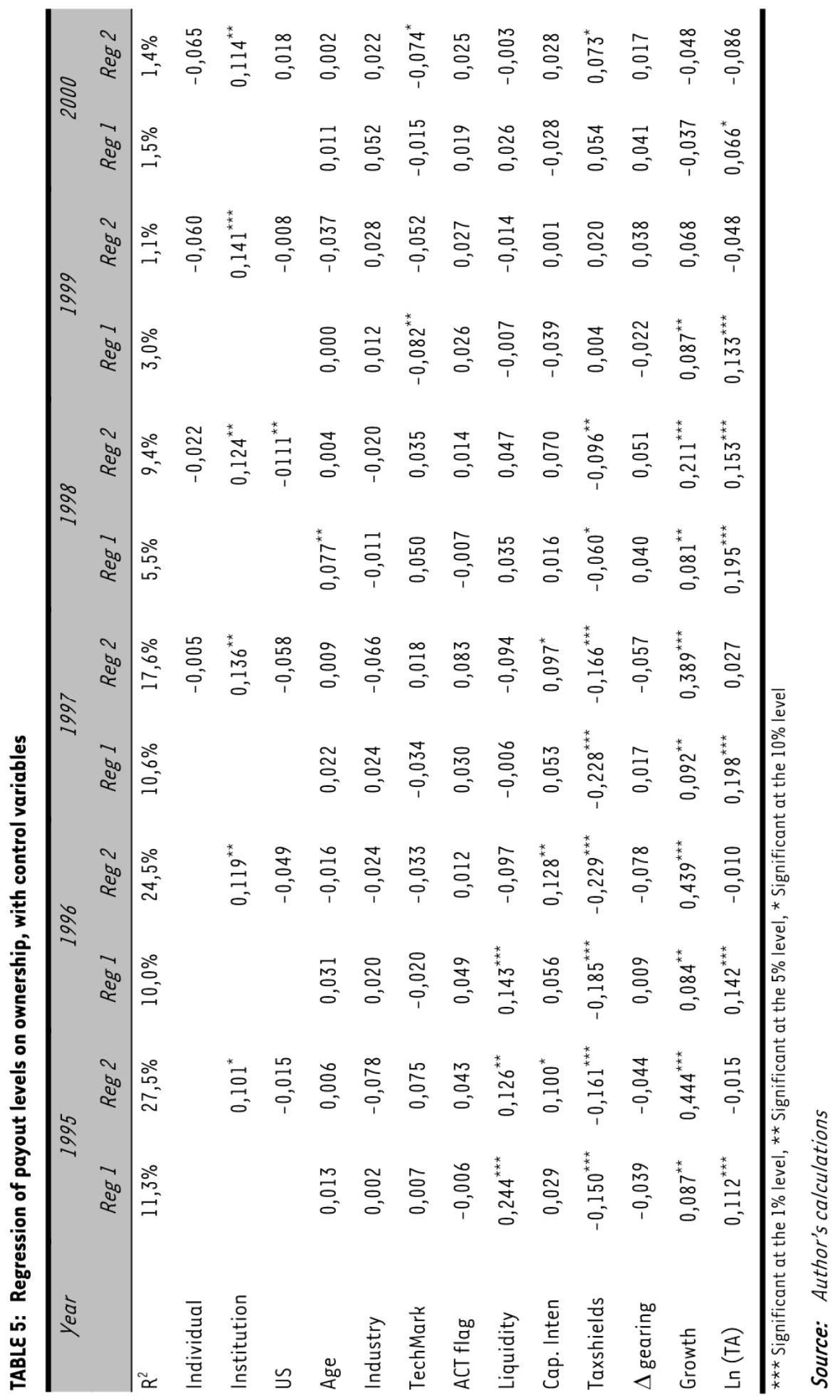


Next, two regressions are run in each year, using payout scaled by total assets as dependent variable. The first (Reg 1 ) uses a series of non-ownership control independent variables. In the second regression (Reg 2), ownership data is added as additional explanatory variables. TABLE 5 (on the previous page) shows the regression coefficients and significance for both regressions in each year.

Non-debt tax shields are significantly negative from 1995 to 1998 in both sets of regressions. This implies that firms paying high dividends have relatively high taxable income. This makes intuitive sense, since high payout generates high ACT, which requires high taxable income to trigger sufficient mainstream CT to absorb it. In 1999, with the phasing out of ACT, the variable is no longer significant. Growth prospects, significant in all years but 2000, have the predicted positive sign in both sets of regressions. The LSE TechMark designation seems a more efficient proxy for industry effects than the three-digit DataStream code.

Size is significant and positive, but, when ownership variables are added, size is dominated by institutional ownership. This is significant in all years, with the expected positive sign, indicating the expected high-payout dividend clientele. The fact that the sign and significance continue undiminished after the tax changes indicate that tax is not the sole driver behind this clientele. Individual ownership has the expected negative sign in all years, indicating that this clientele favours low payout. However, the coefficients are not significant.

The regression results presented in TABL $\boldsymbol{5}$ (on the previous page) confirm the existence of an institutional clientele, based at least in part on tax considerations. There is weak support for the existence of a dividend tax clientele in relation to individual investors.

To test whether British pension funds diversified their investments following the tax change, the annual change in institutional investment is initially regressed on a series of explanatory and control variables. TABLE 6 (on the following page) shows the results.

Prior to the tax changes, changes in institutional investment appear to have been primarily driven by liquidity considerations. This is consistent with the idea that pension funds choose to invest in cash-rich firms which will be in a position to pay high dividends. After the tax changes, the main driver appears to be a desire to invest in technology firms. This is consistent with a rebalancing of portfolios, using new funds to diversify away from the cash-rich firms.

As a second strand of tests, TABLE 7 compares long-run returns before and after the tax changes for firms in the top and bottom quintile of average payout.

TABLE 7: Long-run returns for high and low payout firms

\begin{tabular}{llccc}
\hline \multicolumn{1}{c}{ Return } & All Firms & Low Payout & High Payout & Difference \\
\hline Pre 1997 & 2,3912 & 2,7509 & 1,6560 & 1,0949 \\
Post 1997 & 1,9973 & 5,2372 & 0,5640 & $4,6732^{\star \star \star}$ \\
\hline$* \star *$ & Significantly different at the 1\% level & & \\
$* *$ & Significantly different at the 5\% level & & \\
$*$ & Significantly different at the 10\% level &
\end{tabular}

Source: Tests by author on data, as described above

The results show that, following the tax change, low-payout firms enjoyed significantly higher long-run returns than high-payout firms. This is consistent with the idea that institutional 
investors diversify away from high-payout firms once they were no longer tax-advantaged.

TABLE 6: Regression of changes in institutional investment

\begin{tabular}{|c|c|c|c|c|c|}
\hline & 1996 & 1997 & 1998 & 1999 & 2000 \\
\hline R2 & $11,3 \%$ & $4,9 \%$ & $2,5 \%$ & $7,9 \%$ & $3,9 \%$ \\
\hline Age & $-0,075$ & $-0,008$ & $-0,076$ & $-0,049$ & $-0,007$ \\
\hline Industry & $-0,057$ & $-0,014$ & $-0,032$ & 0,085 & 0,025 \\
\hline TechMark & $0,112^{*}$ & $-0,028$ & $-0,075$ & $0,123^{\star \star}$ & $0,145^{\star \star \star}$ \\
\hline ACT flag & 0,063 & 0,024 & $-0,071$ & $-0,057$ & 0,026 \\
\hline Av. Payout & $-0,100$ & $-0,047$ & $-0,037$ & 0,008 & $-0,055$ \\
\hline Liquidity & $-0,255^{* \star \star}$ & $0,197^{\star \star \star}$ & 0,010 & 0,008 & 0,022 \\
\hline Cap. Intens. & 0,065 & $-0,013$ & $-0,05$ & 0,007 & 0,012 \\
\hline Tax shields & $-0,170^{\star *}$ & $-0,065$ & $-0,039$ & 0,007 & 0,070 \\
\hline$\Delta$ gearing & $-0,007$ & $-0,045$ & 0,027 & $-0,049$ & $-0,002$ \\
\hline Growth & 0,124 & $-0,050$ & $-0,029$ & 0,041 & 0,001 \\
\hline FTSE 350 & 0,064 & $-0,039$ & $-0,008$ & 0,021 & 0,095 \\
\hline $\operatorname{Ln}(\mathrm{TA})$ & $-0,156^{\star}$ & $-0,005$ & 0,095 & $0,205^{\star \star}$ & 0,000 \\
\hline $\begin{array}{l}\text { Sigr } \\
\text { Sigr } \\
\text { Sigr }\end{array}$ & $\begin{array}{l}\text { e } 1 \% \text { level } \\
\text { e } 5 \% \text { level } \\
\text { e } 10 \% \text { level }\end{array}$ & & & & \\
\hline Source: Tes & andata & 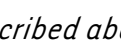 & & & \\
\hline
\end{tabular}

\section{DISCUSSION AND CONCLUSIONS}

Any study of this nature presents hazards in design. The most obvious is that the ownership information may act as a proxy for an important omitted correlated variable. For example, it could be contended that individually-dominated firms may be newer, and so their low payout could have more to do with a trend among younger firms for low payout. The inclusion in the regressions of a wide range of control variables, including industry type, capital intensity and age aims to counter this effect, and adds to the robustness of the results.

In summary, evidence has been presented on the existence of two distinct dividend clienteles in the United Kingdom. Only institutional investors appear to influence payout. The clientele effects appear to be driven by tax, but other factors also contribute. Evidence also shows that, prior to the 1997 tax changes, institutional investors followed a tax-based investment strategy, trading off the tax benefits of dividends against diversification. This strategy reversed for new funds following the abolition of refundable tax credits. However, their existing holdings in highpayout firms were not shed, possibly due to the impact this would have on the value of their stock. 
To answer the questions raised in the introduction: dividend clienteles exist, based on both tax and non-tax factors. Investors will sometimes compromise investment criteria such as portfolio diversification to gain a tax benefit, which implies that shrewd corporate financial managers can gain a strategic advantage by understanding the nature of their clientele's tax needs.

The implications are interesting both for tax policy formulation and for corporate financial management. Shareholder-level taxes clearly matter, particularly for dominant clienteles such as institutional investors. It is important that this is taken into account in devising any change to dividend taxation as well as in tailoring dividend payout. Firms which respond quickly to the changing tax requirements of their dominant clientele will maintain good investor relationships, and find it easier to attract new funds.

\section{Acknowledgement}

The author is grateful for useful feedback on an earlier draft of this paper received at the finance stream of the conference on Adding Value in the Financial World, October 2006, and particularly for the constructive feedback of two anonymous referees for this journal.

\section{REFERENCES}

Bennett, M. \& Donnelly, R. (1993). The Determinants of Capital Structure: Some UK Evidence. British Accounting review, 25(1), pp. 43-59.

Bhattacharya, S. (1979). Imperfect Information, Dividend Policy and the 'bird in the hand' Fallacy. Bell Journal of Economics, 10(1), pp. 259-270.

Bond, S., Chennells, L. \& Devereux, M. (1996). Company Dividends and Taxes in the UK. Fiscal Studies, 16(3), pp. 1-18.

DeAngelo, H., DeAngelo, L. \& Skinner, D. (1992). Dividends and Losses, Journal of Finance, 47(5), pp. 1837-1863.

Easterbrook, F. (1984). Two Agency Cost Explanations of Dividends. American Economic Review, 74(3), pp. 650-659.

Fama, દ. \& French, K. (1998). Taxes, Financing and Firm Value. Journal of Finance, 53(3), pp. 819-843.

Fama, \&. \& French, K. (2000). Disappearing dividends: changing firm characteristics or lower propensity to pay? Centre for Research in Security Prices (Working Paper No. 509), pp. 819-843.

Gordon, M. (1963). Optimal Investment and Financing Policy. Journal of Finance, 18(2), pp. 264-272.

Lasfer, M. (1995). Agency Costs, Taxes and Debt: The UK Evidence. European Financial Management, 1(3), pp. 265-285.

Miller, M. \& Modigliani, F. (1961). Dividend Policy, Growth and the Valuation of Shares. Journal of Business, 34(4), pp. 411-433.

Miller, R., Morris, M. \& Scanlon, K. (1994). Capital Structure and Tax Status: New Evidence from IPOs. Journal of Accounting, Auditing and Finance, 9(2), pp. 197-210.

Poterba, J. \& Summers, L. (1985). The Economic Effects of Dividend Taxation, in Altman, ع. \& Subrahmanyam, M. Recent Advances in Corporate Finance. Illinois, USA: Irwin Inc.

Robinson, G. (2000). The Unconventional Minister: My Life Inside New Labour. London: Penguin Group. 
Scholes, M. \& Wolfson, M. (1992). Taxes and Business Strategy. Chicago: Prentice Hall.

Shackelford, D. \& Shevlin, T. (2000). Empirical Tax Research in Accounting, JAE Rochester Conference. Available from: http://ssrn.com/abstract $=235796$ or D0I: 10.2139/ssrn.235796. (Accessed on 15 December 2004).

Wald, J. (1999). How Firm Characteristics Affect Capital Structure: An International Comparison, Journal of Financial Research, 22(2), pp. 161-187.

Walsh, દ. \& Ryan, J. (1997). Agency and Tax Explanations of Security Issuance Decision. Journal of Business Finance and Accounting, 24(7), pp. 943-961. 
